\title{
Evaluation of dryland species and new ryegrass cultivars to increase pasture productivity in coastal Taranaki
}

\author{
R.J. HAINSWORTH ${ }^{1}$, N .A. THOMSON', D.A. McCALLUM ${ }^{1}$ and T.G. JUDD' \\ ${ }^{1}$ Taranaki Agricultural Research Station, DRCC, Normanby \\ 'Flock House Agriculture Centre, MAF Technology, Bulls
}

\begin{abstract}
Seasonal and annual DM production of direct drilled dryland species 'Grasslands Maru' phalaris (Phalaris aquatica L.) and 'Grasslands Roa' tall fescue (Festucaarundinacea Schreb.) and perennial ryegrass (Loliumperenne L.) cultivars 'Grasslands Pacific', 'Droughtmaster' and 'Yatsyn-1' was compared with that of established pasture in an environment prone to summer dry spells. Two methods of establishment using only Yatsyn-1 were examined: either the elimination of existing pasture with glyphosate and drilling, or drilling without spraying (undersowing).

Average annual DM production (over 3 years) of Yatsyn-1 drilled into pasture previously sprayed with glyphosate was $12 \%$ more productive than established pasture. Maru phalaris, Droughtmaster and Pacific had similar annual DM production to established pasture, and Roa tall fescue produced $25 \%$ less. Yatsyn-1 undersown intopastures without previous spraying with glyphosate produced $9 \%$ less than $\mathrm{Y}$ atsyn- 1 established by the spray and drill technique.

Phalaris established well but after 3 years the content of phalaris had declined markedly, suggesting poor persistency. Tall fescue was slow establishing but had good persistency, as did all ryegrass cultivars.

Yatsyn-1 direct drilled into pastures eliminated with glyphosate before drilling is recommended for an environment prone to summer dryness to increase annual DM production.
\end{abstract}

Keywords pastureproduction,establishedpasture, ryegrass cultivars, phalaris, tall fescue, establishment techniques, summer droughts

\section{Introduction}

Summer dry spells in coastal Taranaki occur one in every three years (Roberts \& Thomson 1984). Pastures here are predominantly ryegrass/white clover and are unproductive during periods of soil moisture deficit. Possible means of increasing summer pasture productivity are through irrigation, which is expensive, or by introducing drought-tolerant species or new improved ryegrass cultivars. Tall fescue and phalaris have been recognised as pasture species tolerant to drought and grass grub (Kain \&Atkinson 1977). In trials at the Taranaki Agricultural Research Station, tall fescue and phalaris produced $15 \%$ and $17 \%$ more than established pasture respectively (Judd et al. 1989). New improved ryegrass cultivars are also proving effective in increasing dry matter (DM) productivity, especially over summer and autumn (Kerr et al. 1987).

When renovating pastures the method of establishment must ensure a persistent and productive pasture. Thorn et al. (1985) found that spraying with a herbicide before drilling was better than undersowing (drilling directly into pasture without spraying with a herbicide); however, undersowing is still common.

Thevalueofdrylandspeciesornew ryegrasscultivars to increase DM productivity was evaluated at a southern site in coastal Taranaki. Two establishment methods were also examined.

\section{Materials and Methods}

The trial was conducted in coastal Taranaki from autumn 1987 to spring 1990 with measurements beginning in spring 1987. A northern (Okato) and a central (Hawera) site were used for observations (plant counts in May 1987 and each subsequent autumn, point analysis) and a southern (Patea) site for pasture production and again point analysis for determining persistency of the respective species.

The existing pasture (left unsprayed) was compared over 3 years with 3 perennial ryegrass cultivars ('Yatsyn1', 'Grasslands Pacific', and 'Droughtmaster') and two dryland species 'Grasslands Maru' phalaris (Phalaris aquutica L.) and 'Grasslands Roa' tall fescue (Festuca arundinacea Schreb.)). Established pasture was also compared with Yatsyn-1 established by spraying with glyphosate before drilling and Yatsyn-1 undersown (no spray used). A randomised block design, with 3 replicates, was used with plot size $4.9 \mathrm{~m} \times 20 \mathrm{~m}$. All sown treatments (exduding undersown Yatsyn- 1) were sprayed out with glyphosate at 3 //ha 1 week before drilling. Ryegrass and phalaris were sown at $12 \mathrm{~kg} / \mathrm{ha}$ and tall 
fescue at $25 \mathrm{~kg} / \mathrm{ha}$, all with Pitau white dover at $3 \mathrm{~kg} / \mathrm{ha}$ using a triple disc drill, in April 1987.

The trial areas were rotationally grazed with dairy cows. Production auts were taken 12 times per year to 4 $\mathrm{cm}$ height with a rotary mower (one strip $10 \mathrm{~m}$ long per plot) before grazing, with a new area trimmed after grazing. Point analysis was done each autumn to determine botanical composition. Species identified were sown species, other grasses, white clover (Trifolium repens), weed and dead matter.

Results

\section{Total herbage dry matter production}

(a) Establishment

There was no consistent effect between sites of grass species onplantnumbers at establishment. Thenorthern and central sites had fewer plants. At the northern site, tall fescue established significantly better than the ryegrasses and phalaris. Pacific and Droughtmaster established significantly better than the other grasses at the southern site. Droughtmaster again had superior plant numbers at the central site.

In general Yatsyn established by spraying before drilling and phalaris were the poorest establishing at all sites.

(b) Species and cultivar effects

Table 1 Average. seasonal and annual DM production (kg DM/ha) of dryland species and ryegrass cultivars average for three. years.

\begin{tabular}{|c|c|c|c|c|c|c|}
\hline & & Winter & Spring & Summer & Autumn & Annual \\
\hline Yatsyn $\cdot 1$ & & 1630 & 3560 & 2190 & 1320 & 6920 \\
\hline Droughtmaster & & 1420 & 3530 & 1790 & 1140 & 7670 \\
\hline Pacific & & 1660 & 3500 & 1660 & 1170 & 6210 \\
\hline Established & Pasture & 1420 & 3210 & 2160 & 1170 & 7960 \\
\hline Phalaris & & 1630 & 2640 & 1990 & 1340 & 6010 \\
\hline Tall fescue & & 1160 & 2650 & 1670 & 920 & 6420 \\
\hline Significance & & .. & & NS & NS & ' \\
\hline $\operatorname{LSD}_{005}$ & & 306 & 640 & - & - & 1330 \\
\hline $\operatorname{LSD}_{0.01}$ & & 366 & - & - & - & - \\
\hline
\end{tabular}

In winter, Yatsyn-1 and phalaris produced significantly $(\mathrm{P}<0.01)$ more than tall fescue, Droughtmaster and established pasture (Table 1), and Pacific produced significantly $(\mathrm{P}<0.01)$ more than tall fescue. In spring, Yatsyn-1 , Droughtmaster and Pacific were significantly $(\mathrm{P}<0.05)$ more productive than tall fescue and phalaris. Dryland species or ryegrass cultivars did not differ significantly in summer and autumn, although DM production of Yatsyn- 1, established pasture andphalaris was greater than that of other species in summer. In autumn Yatsyn-1 and phalaris were again more productive.

A verage annual DM production of the ryegrass cultivars andphalaris was significantly $(\mathrm{P}<0.05)$ higher than that of tall fescue. Although other treatments did not differ significantly, Yatsyn-1 produced (kg DM/ha) 1050, 960, 910 and 710 more than Droughtmaster, established pasture, phalaris and Pacific, respectively.

\section{(c) Establishment method}

In winter, Yatsyn-1 established by the spray and drill method produced significantly $(\mathrm{P}<0.01)$ more DM than undersown Yatsyn-1 and established pasture (Table 2). Establishment method had no signifcant effect on DM production in the other seasons or on annual average DM production. Annual DM production for Yatsyn-1 established by the spray and drill method was 960 and $710 \mathrm{~kg} \mathrm{DM} / \mathrm{ha}$ more than established pasture and undersown Yatsyn-1, respectively.

Table 2 Average seasonal and annual DM production (kg DM/ha) spray and drill versus undersowine average for three years.

\begin{tabular}{lcccccc}
\hline & & Winter & Spring & Summer & Autumn & Annual \\
\hline Yatsyn-1 + & herbicide & 1630 & 3560 & 2190 & 1320 & 6920 \\
Yatsyn-1 * herbicide & 1430 & 3370 & 1790 & 1140 & 7670 \\
Established & Pasture & 1430 & 3210 & 2160 & 1170 & 7960 \\
Significance & *1 & NS & NS & NS & NS \\
LSD $_{0.05}$ & 306 & $*$ & $*$ & . & - \\
LSD $_{0.01}$ & 360 & & & * & . \\
\hline
\end{tabular}

\section{Botanical composition}

From year one to year two, at all sites, sown species content increased, then from year two to three sown species content dedined (Figure 1). Ryegrass content of undersown Yatsyn-1 and established pasture did not differ significantly.

In year one, Yatsyn-1 established by the spray and drill method had significantly $(\mathrm{P}<0.05)$ higher ryegrass content than established pasture at the northern and central sites. In year two, this was significant at the central site only, and by year three there were no significant differences.

Differences inryegrass contentbetween theryegrass cultivars were significant $(\mathrm{P}<0.05)$ in year one and two. In year one, there were no significant differences at the southern site; at the northern and central site, Yatsyn-1 was significantly superior to Padific; and at the central site Droughtmaster was superior to Pacific. In year two, there were no significant differences at the southern site at the northern and central sites, Yatsyn-1 and Droughtmaster were not significantly different but had 

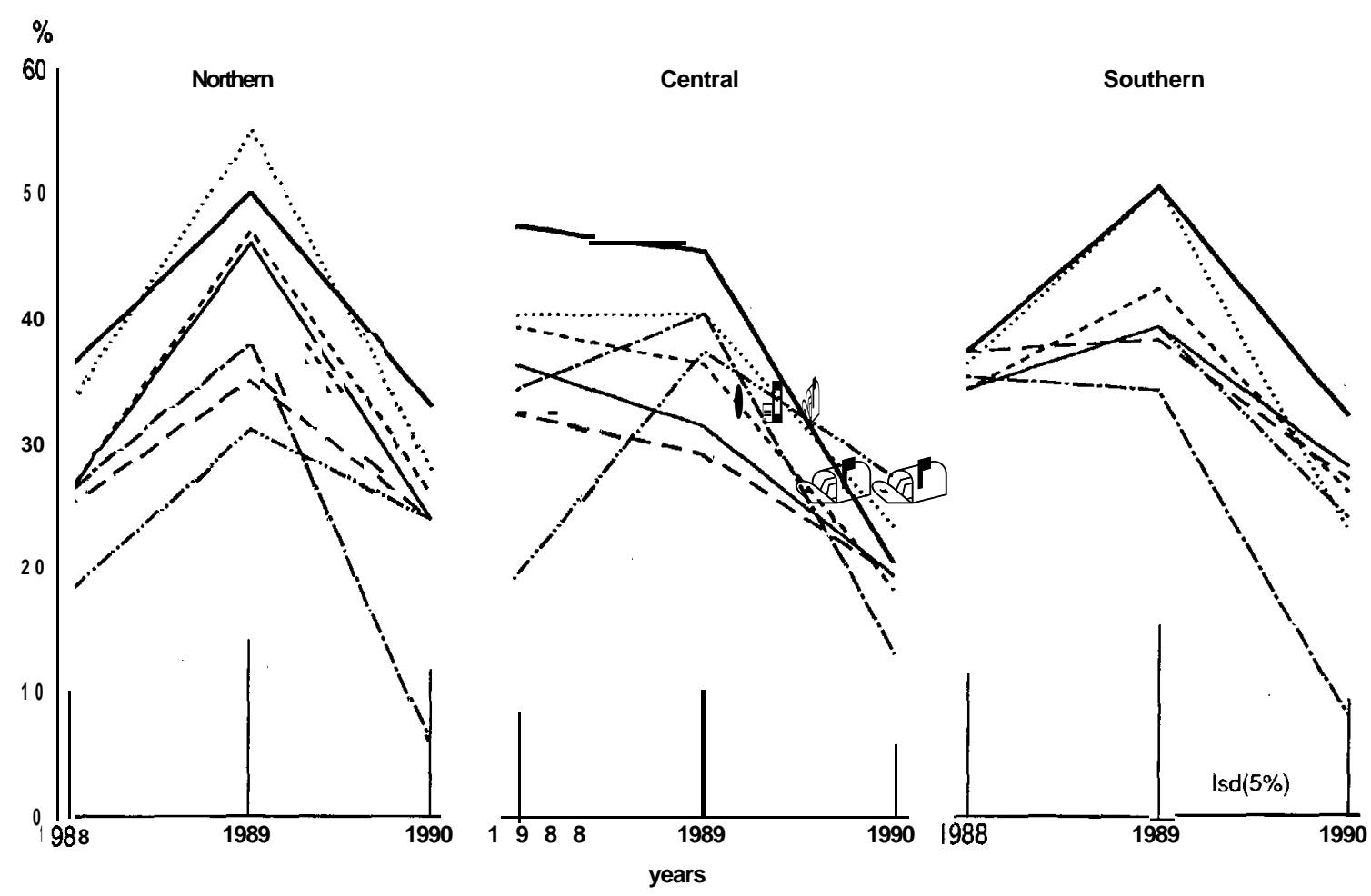

\begin{tabular}{|c|c|c|c|}
\hline $\begin{array}{l}\text { Yatsyn_1 + herbicide } \\
\text { Tall Fescue }\end{array}$ & $\begin{array}{l}\text { Yatsyn_1 } \cdot \text { herbicide --- } \\
\text { Phalaris } .=\text {. }\end{array}$ & $\begin{array}{l}\text { Droughtmaster .... } \\
\text { Established pasture }\end{array}$ & Pacific --- \\
\hline
\end{tabular}

Figure 1 Sown species content of dryland species and ryegrass cultivars.

a significantly $(\mathrm{P}<0.05)$ higher ryegrass content than Pacific.

In year one, at the northern and central sites, sown species content of tall fescue was significantly $(\mathrm{P}<0.05)$ lower than that of phalaris and established pasture. By year two, the content of tall fescue at all sites had increased and was not significantly different from either phalaris or established pasture. In year three, the content of phalaris was significantly lower than that of all other species.

For all sites content of other grasses, clover and dead matter was high. Point analysis was conducted each autumn and dead matter, content on all treatments was high (20-40\%). Dead matter content was significantly lower in phalaris that in all other treatments. Clover and other grasses content was higher in both tall fescue and phalaris than in ryegrass cultivars $(29 \%$ clover in tall fescue and phalaris vs. $19 \%$ in ryegrasses).

\section{Discussion}

The average DM production of tall fescue over the three years was $25 \%$ less than that of established pasture. Phalaris produced similarly to established pasture.
Therefore, tall fescue and phalaris would not be a recommended pasture species for coastal Taranaki. In contrast, Judd et al. (1989)reportedthatphalaris and tall fescuecouldberecommendedas alternatives toryegrass in the grass grub prone, summer dry environment of south Taranaki. Judd et al. (1989) also reported that over time, the productivity of phalaris dedined, suggesting that it may not persist as well as tall fescue. Despite the slow establishment of tall fescue at the northern and central sites, the content of tall fescue increased in the second year, and by the third year at the central site tall fescue had the highest sown species content, indicating good persistence. Phalaris established well at all sites but by 1990 the sown species content was very low, suggesting poor persistency. These observations are surnmarised in Table 3, which highlights the lack of persistency of phalaris. The poor production from tall fescue and phalaris may have been due to the method of establishment. In recent years it has been recommended that the most successful method to establish tall fescue and phalaris is by cultivation (McCallum \& Thomson 1990). Over the trial it was observed that tall fescue was grazed more intensely than ryegrass. This did not appear to affect persistency (Figure 1), but might have affected 
productivity (Table 1). Productivity of tall fescue and phalaris might have been greater if they had been established through cultivation.

Yatsyn-1 was the superior ryegrass cultivar, producing on average $12 \%$ more than established pasture over the three years, confirming the results of Kerr (1989). Average annual DM production of Pacific and Droughtmaster weresimilar to that ofestablishedpasture (Table 1).Theryegrass content of Yatsyn-1 was superior to that of established pasture, suggesting that Yatsyn-1 establishes and persists well in a summer dry environment. Yatsyn- 1 and Droughtmaster had a higher content of ryegrass than Pacific over the three year5 at all sites except at the southern site in 1988, suggesting that Pacific did not establish as well as either Yatsyn-1 or Droughtmaster (Table 3). However, although Pacific had poor establishment, it persisted as well as if not better than other ryegrasses (Table 3).

Table 3 Botanical composition average decline in percentage units of sown species content from 1988 to 1990

\begin{tabular}{lc}
\hline Treatment & Decline \\
\hline Yatsyn-1 & -11 \\
Droughtmaster & -11 \\
Pacific & -8 \\
Tall fescue & +1 \\
Phalaris & -23 \\
Established pasture & -8 \\
\hline
\end{tabular}

Drilling into pasture eliminated with glyphosate was the superior method of establishing perennial ryegrass. Yatsyn-1 drilled into previously sprayed pastures produced $12 \%$ and $9 \%$ more DM than established pasture and undersown Yatsyn-1 respectively (Table 2). This result confirms recommendations by Thorn (1985) and Baker (1980). The pastures in which these trials were established were not severely run out and therefore the results may have differed if the pastures were in need of renovation.

The result5 have confirmed earlier reported trends by other authors. The trial was conducted under practical farming condition 5 and as such the results may truly reflect the production and persistency of pasture species established by the direct drilling method. That the productivity of tall fescue and phalaris differs from that previously reported does highlight the possible bias that establishment method and trial management have on experimental work.

\section{ACKNOWLEDGEMENTS}

The author5 wish to thank Noel Schrider, Les Bent and Graeme Kelly for providing the trial sites and particularly $\mathrm{Nol}$ for co-ordinating the grazing management.

\section{REFERENCES}

Baker, C.J.; 1980. Renovation of pastures. Proceedings of the Ruakura Farmers' Conference 32: 53-61.

Judd, T.G.; Thomson, N.A.; McCallum, D.A.; 1989. Pasturemanagementandpasturespeciesforimproved dry matterproduction in South Taranaki. Proceedings of the NZ Grassland Association 51 :109-1 12.

Kain, W.M.; Atkinson, D.S.; 1977.Development of resistant pastures and methods of pasture management for grass grub (Costelytra Zealandica [white])contml. NZjournal ofagricultural research 21: $501-511$.

Kerr, G.A.; 1987. Evaluation of fourperennial ryegrass cultivars in New Zealand. Proceedings of the NZ Grassland Association 48:137-141.

Kerr, G.A.; Goold, G.; Judd, T.; 1989. Comparison of high endophyte perennial ryegrass cultivars in the Waikato and Taranaki. Proceedings of the Large Herds Conference 20:44-45.

McCallum, D.A.; Thomson, N.A.; 1990.Effect of molluscicide and an insecticide on the establishment of direct drilled ryegrass, tall fescue and phalaris. Proceedings of the NZGrasslandAssociation 52:237. 240.

Roberts, A.H.C.; Thomson, N.A.; 1984.Seasonal distribution of pasture production in New Zealand XVIII South Taranaki. NZ journal of experimental agriculture 12:83-92.

Thorn, E.R.; Thomson, N.A.; Clayton, D.G.; 1985. Establishment and management of suitable species in dairy pastures. In Burgess, R.E.; Brock J.L.; Using herbage cultivars Grasslands Research and Practice Series No. 3:71-76. 